\title{
DOUBLE-SKIN FACADES IN HEALING ENVIRONMENTS: AN APPROACH FOR ENHANCING DAYLIGHTING PERFORMANCE IN SOUTH-ORIENTED PATIENT ROOMS IN CAIRO, EGYPT
}

\author{
Noha Al-Shafaey ${ }^{1}$, Morad Abdelkader ${ }^{2}$, Hanan Sabry ${ }^{2}$, and Ashraf Nessim ${ }^{3}$ \\ 1 Masters Candidate, Department of Architecture, Faculty of Engineering, Ain Shams \\ University., E-Mail: Noha.Alshafaey @gmail.com \\ ${ }^{2}$ Professor of Architecture and Environmental Control, Faculty of Engineering, Ain Shams \\ University. \\ 3 Assistant Professor, Department of Architecture, Faculty of Engineering, Ain Shams \\ University.
}

\begin{abstract}
Daylighting provision is an efficient approach in achieving a healing environment. Several researches praised the effect of daylight on stress reduction, shorter hospital length of stay, and the increasing of patients' satisfaction. The building façade has the primary role in controlling the indoor environment. In addition to daylighting, Double-Skin Façade (DSF) is an approach that can create a balance between patients' needs without sacrificing energy reduction and thermal comfort in the hot arid desert climate. This paper aimed at investigating the effect of fixed horizontal louvers integration in a multi-story double-skin façade to enhance daylighting performance and visual comfort in south-oriented patient rooms located in Cairo, Egypt. Rhinoceros software was used for modeling the proposed designs coupled with Diva-4-Rhino for daylighting simulations. The effect of changing louver's depth and slats' number resulted in 16 designs that were modeled for examination. Daylighting performance was analyzed by two metrics; Spatial Daylight Autonomy (sDA) and Annual Sunlight Exposure (ASE) on both the room surface floor and bed surface planes to represent daylight distribution and visual discomfort, respectively. Results showed that all cases were successful, achieving $100 \%$ sDA value on the bed plane area. However, the SDA and ASE values at the room floor area were different. Three louvered double-skin façade designs have succeeded in meeting SDA and ASE acceptance criteria and were recommended for integrating in patient rooms. Also, it was noticed that the unshaded double-skin façade presented the worst performance.
\end{abstract}

Keywords: Healing environment, Double-Skin façade (DSF), Patient Rooms, Daylighting Performance, Spatial Daylight Autonomy (sDA), Annual Sunlight Exposure (ASE) 


\section{Introduction}

Hospital's environment is one of the leading causes of stress for patients, which makes a complicated and long recovery process. As a result, creating a healing environment became the focus of any hospital design process to promote patients' comfort. The concept of healing environment points towards the ability of the physical healthcare environment to make a difference in patients' recovery process (Ghazali \& Abbas, 2012). As stated by Harris, et al. (2002), visual comfort has a significant role as one of the physical environment factors that contribute to creating a healing environment along with other factors, as shown in Figure (1).

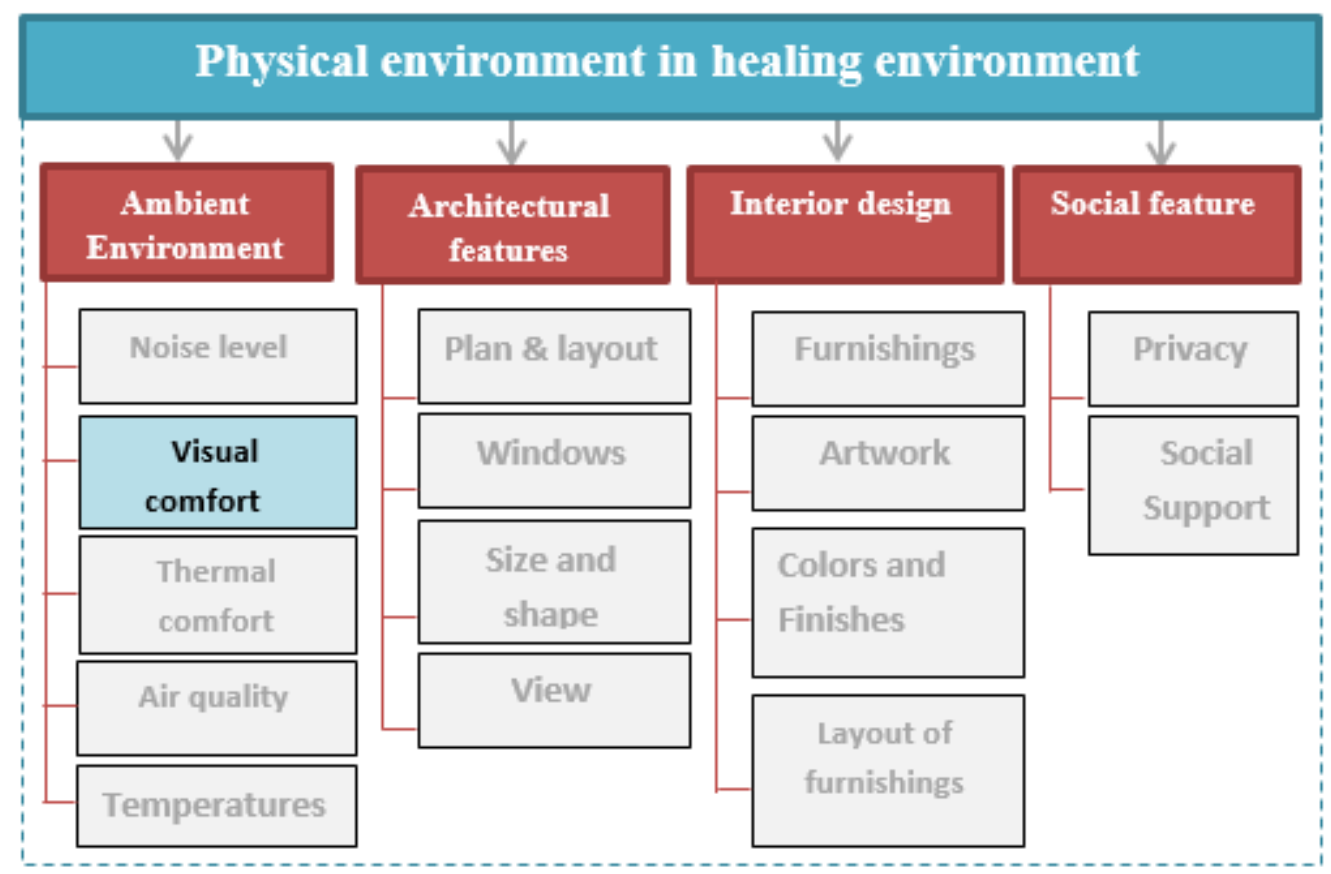

Figure (1): Physical environment factors that affect the healing environment highlighting visual comfort. Source: Developed by the researcher after (Harris et al. , 2002).

Daylight incorporation in healing environments has a profound positive influence on the health and well-being of patients physiologically, mentally, and psychologically as found in numerous publications (Walch, et al., 2005). Daylight improvement could reduce stress and pain, improve alertness, regulate the circadian system, improve patient safety, and enhance the overall healthcare quality (Ulrich, 1991). Joseph (2006) stated in an article, the importance of incorporating daylight in hospital design. Another attempt by Choi, et al. (2012) investigated the daylight effect on patient's average hospital length of stay to reach a healing environment. The study found that daylight incorporation had a significant role in reducing the patient's length of stay.

Another questionnaire-based study addressed the influence of daylight on hospital staff needs and satisfaction (Alzubaidi, et al., 2013). Most of the addressed doctors and nurses emphasized the importance of daylight exposure in patient rooms as it aids them in 
patient's treatment and observation, facilitating their work, promoting fast recovery and reduction of patients' length of stay, and enhancement of staff satisfaction.

Another group of more related publications addressed the external façade and its window openings to enhance the daylighting performance in patient rooms. In a study done by Shikder et al. (2010), the authors investigated window openings optimization through parametric computer simulation to determine the optimum widow design, dimensions, and depth of the suitable shading device. In another study, the influence of room shape and its optimum window to wall ratio in providing adequate daylight in south-oriented three of the most commonly used patient room layouts located under the clear sky of Cairo, Egypt. Results showed that nested and inboard bathrooms patient room layouts proved to be most successful in providing daylight with an acceptable range of window to wall ratio. However, the outboard bathroom layout provided a limited range of window to wall ratio (Sherif, et al., 2014a).

Another related research addressed the enhancement of daylighting and external view exposure of hospital patient rooms as a means to achieve a "Salutogenic" hospital which aims at creating a health-promoting design of healthcare facilities (Sherif, et al., 2014b). The study focused on the use of a parametric optimization process for determining the optimum window size and shading system related to three patient room layouts in Cairo, Egypt. Results showed that the nested bathroom achieved $96 \%$ and $83 \%$ daylit room area was due to the success of the optimized external wall configuration in north and south directions, respectively. The inboard bathroom was second best when oriented towards the north direction achieving 89\% daylit area. In all cases, the patient-bed surface was $100 \%$ daylit. In the relation of external view exposure, the highest exposure was achieved by the north-oriented inboard bathroom patient-room design

Another paper investigated the effect of using shading and daylighting systems on the daylighting performance of an intensive care unit located under the clear sky of Cairo, Egypt (Sherif, et al., 2013). Results came with recommended window configurations for different window to wall ratio in each orientation. A research analyzed window configurations for an intensive care unit to reach visual comfort and energy saving (Sherif, et al., 2015). Results showed that horizontal sun breakers and solar screens produced a better performance in a broader range of window to wall ratio than other alternatives.

In another research by Sherif et al. (2016), the daylighting performance of horizontal blind slats with different shapes was investigated in an outboard bathroom patient room located in Cairo, Egypt (Sherif, et al., 2016). Parametric tools and simulations were conducted to test 77 possible slat shapes that achieve the criteria of $100 \%$ daylit bed surface area and $55 \%$ of the patient room area and also to maximize external view accessibility. Results showed that flat-shaped slats or gently curved achieved better results in both daylighting and external view exposure.

Wagdy et al., (2017) investigated the main characteristics of sun breakers to control solar access in south-oriented inboard and outboard bathroom hospital patient room under the clear sky of Cairo, Egypt. He targeted the effect of cut-off angles and their corresponding tilt angles. Results showed that horizontal sun breakers were achieved the most successful performance in both layouts in all tested window to wall ratio. The paper concluded that 
the cut-off angle was more influential than the tilt angle in providing adequate daylighting performance (Wagdy, et al., 2017).

The above-discussed literature showed that the external patient room façade and window configuration have a crucial effect on the daylighting performance and the patient's visual comfort. In addition to daylighting, the façade has the primary role in providing thermal comfort, proper ventilation, energy reduction, and connection with outdoors. Balancing these roles to meet patients' needs is quite a challenge in hot arid desert climate due to the abundance of solar penetration.

Double skin facades are highly glazed structures that can provide an abundance of daylight to the interior space even under overcast conditions (Ghaffarianhoseini, et al., 2016). Double-Skin facades have presented an efficient solution for controlling the indoor and outdoor environments interaction (Ghasemi \& Ghasemi, 2017). Moreover, the system's cavity is considered as a buffer zone that helps in protecting the inner glazed surface and provides a secure gap for installing proper shading elements (Oesterle, 2001). Therefore, DSFs represents an approach that can achieve a balance between thermal comfort, visual comfort, and energy reduction in patient rooms.

Several classifications have been made to double-skin façades; Façade geometry, ventilation principle, and airflow types. However, from a daylighting point of view, the façade geometry DSF classification seems to be the most relevant classification that can affect daylighting performance. Oesterle et al. (2001) had classified DSF according to the geometry (i.e., partitioning) of the façade into for main types; Box-window façade, Shaftbox façade, corridor façade, and Multi-story façade. This classification is well-known and used through most of the recent publications. In this paper, the multi-story DSF type was investigated. Multistory DSF includes cavity space between the inner and the outer skins. It extends over the entire façade without any dividers (Aksamija, 2009).

Several studies addressed the Double-Skin façade system from thermal, ventilation, and energy performance points of view. However, very little research investigated the daylighting performance of double-skin façade. A study done by Hamza et al. (2007) conducted a simulation-based analysis of the thermal and daylight performance of a corridor and multistory DSF in an office building located in hot arid climate. In terms of daylighting performance, Radiance software was used to test the indoor luminance level. Results showed that the two DSF types produced different indoor illuminance maps. The resulted luminance levels were different in distribution, but in both cases, average luminance levels seem to provide adequate daylight levels indoors.

A research done by El Ahmar \& Fioravanti (2015) investigated the application of a DSF with folded façade geometry for the improvement of thermal and daylight performances of an office room in Cairo. Grasshopper Plugin for Rhino 3D software was used to model the proposed façade and compare it to the reference case represented by a real office building as well as a flat conventional DSF designed based on observations from previous studies. Results indicated that the folded façade provided self-shading, improving daylighting performance, achieving a proper reduction in cavity temperature, and decreasing the cooling loads improving daylight performance. 
In hot climate, Double skin façades can introduce excessive glare at certain times of the day, which raises the need for further design measures to solve their harmful effects. Solar shading systems can be an effective solution to control glare problems assuring visual comfort. Louvers are usually paired with the double-skin facade as a solar shading technique (Mahdavinejad \& Mohammadi, 2016). Horizontal louvers are essential for providing solar shading in south facades in especially in hot and Mediterranean climates (Mahdavinejad \& Mohammadi, 2016). Louvers integration in DSF is influenced by several parameters that can affect the performance of the DSF system (Parra, et al., 2015). These design parameters included the shape, position, size, inclination angle distance from the facade in addition to shape, color, and material (Mahdavinejad, 2016).

The reviewed literature showed that several studies addressed the daylighting performance of DSF indirectly while evaluating the performance of other effects, which resulted in limited researches related to specific buildings (Aksamija, 2017). Through the research period, there was no research found discussing the effect of using a double-skin façade in patient rooms. Therefore, this paper is mainly concerned with addressing these knowledge gaps to create a broader understanding of the daylighting performance of DSF and its influence on occupants' visual comfort.

From the demonstrated literature, it can be concluded that Double skin façade can offer appropriate daylight provision in patient rooms without enduring sacrifices in the overall building performance. In this way, maximum daylight can be maintained for every patient, besides the possibility of looking at the natural views directly through the room window. Proper design of DSF with proper shading system could enhance daylighting performance and create a healing environment in patient rooms.

\section{Objective}

The aim of this paper is enhancing the daylighting performance of double-skin façade to reach an adequate healing environment in hospital patient rooms. The main objective of this study is to investigate the effect of horizontal louvers integration in a double-skin façade to achieve visual comfort in south-oriented patient rooms located in Cairo, Egypt. The focus is on the effect of changing the louver's depth and number of slats on annual daylight distribution and visual discomfort to attain satisfactory double-skin façade designs that maximize utilization of daylighting in hospital patient rooms.

\section{Methodology}

The adopted methodology in this paper analyzed daylighting adequacy for a generic southoriented hospital patient room on the second floor of a hospital located in Cairo, Egypt. Double-skin facade was used as the room façade, and horizontal louvers integration was investigated. Two parameters of the horizontal louvers were considered variables; louver's depth and louvers slats' number. Figure (2) illustrates the research methodology. 


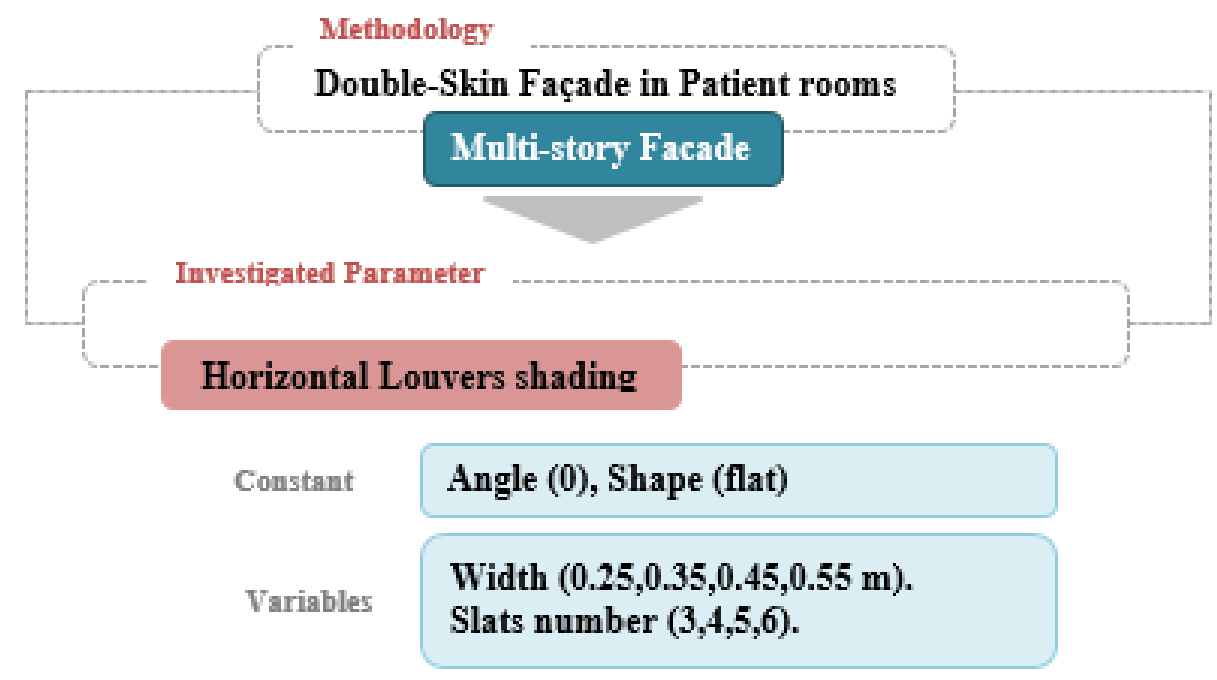

Figure (2): The Methodology of the research

\subsection{Base Case and Modeled Cases Parameters}

The base case was represented by a hospital patient room with a double-skin façade with no shading system. The simulations took place in a typical inboard-bathroom hospital patient room, where the patient bathroom was located on the internal wall of the building adjacent to the corridor, as shown in Figure (3). The selected design is considered one of the standard hospital patient room layouts in Egypt. The design, dimensions, and properties of the space are discussed in Table (1). The studied room is located on the second floor of a hospital located in Cairo, Egypt (30_60N, 31_240E, alt.75 m). The city is characterized by its hot-arid desert climate and enjoys a predominantly clear-sky (Köppen-Geiger, 2006). The patient room was south oriented to allow for maximum exposure of direct sunlight. The room window has a Window to Wall Ratio (WWR) of $65 \%$ with no external obstructions.

A multi-story naturally ventilated DSF was used as the external façade of the hospital patient room. A $1 \mathrm{~m}$ cavity depth was selected as recommended by studies that showed that $1 \mathrm{~m}$ cavity depth could emphasize the stack effect and create a balance between air extraction and heat transmission to the user room (Rahmani, et al., 2012; Radhi, et al, 2013). As recommended by Barbosa (2014), single glazing was used for the outer layer and double glazing was used for the inner layer to reduce the radiative and conductive components of heat transfer across the façade and achieve higher airflow by increasing the air temperature in the cavity. Parallel horizontal flat-shaped louvers were selected as solar shading system to be integrated inside the DSF cavity positioned on the inner layer. Two design parameters of these louvers were studied; The louver's depth and the louvers slat's number. As illustrated in Table (2), the changing effect of the two parameters has produced 16 modeled DSFs designs. 


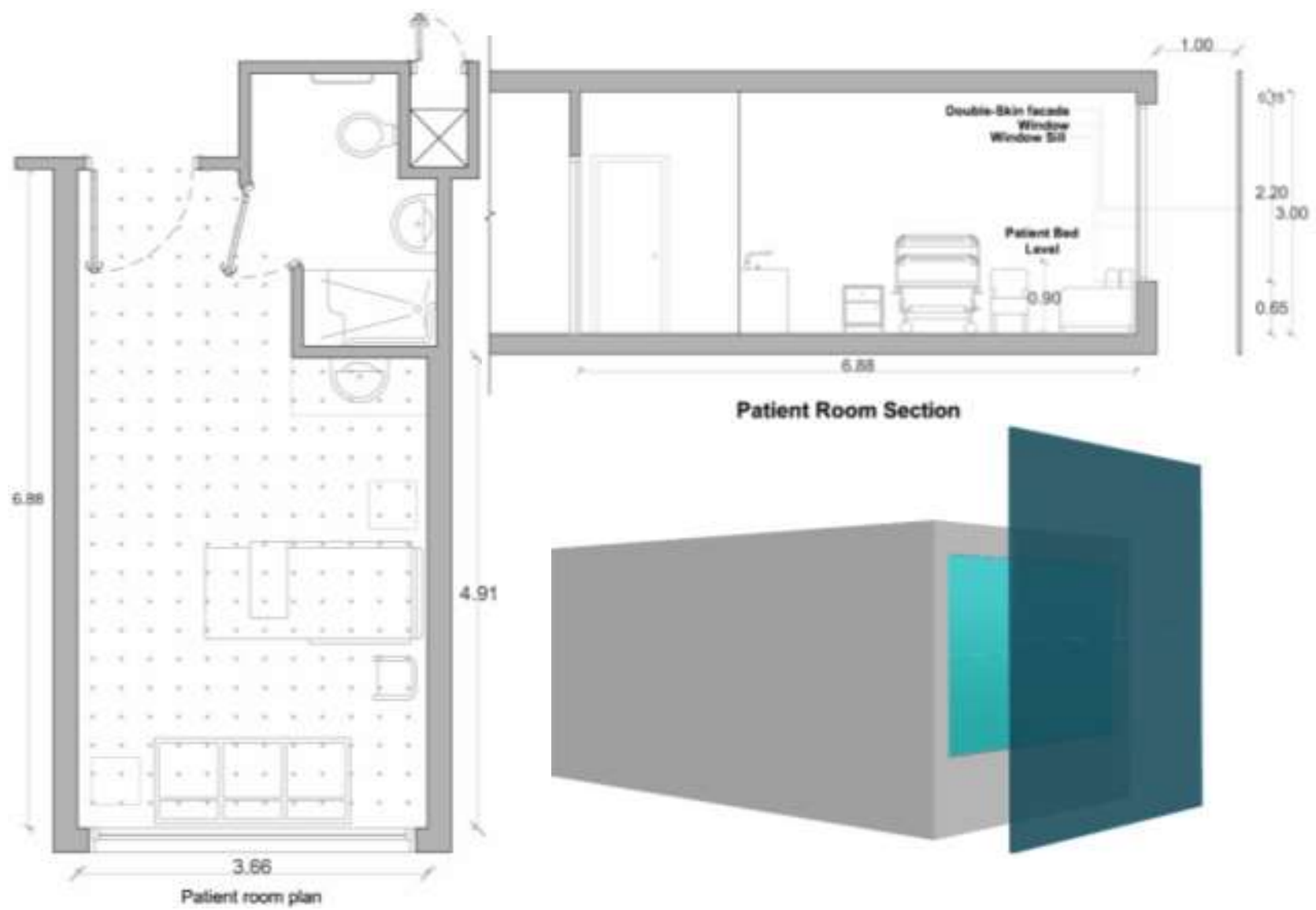

Fig. (3): Floor plan, section, and a perspective shot of the tested patient room without DSF daylighting.

Table (1): Dimensions and parameters of the tested patient room

\begin{tabular}{|c|c|c|}
\hline \multicolumn{3}{|l|}{ Patient room parameters } \\
\hline \multicolumn{2}{|l|}{ Floor level } & Second level $(+6 \mathrm{~m})$ \\
\hline \multicolumn{2}{|l|}{ Area $\left(\mathrm{m}^{2}\right)$} & $22 \mathrm{~m}^{2}$ \\
\hline \multirow[t]{2}{*}{ Walls } & Reflectance & $50 \%$ \\
\hline & Material & Medium colored interior walls \\
\hline \multirow[t]{2}{*}{ Ceiling } & Reflectance & $80 \%$ \\
\hline & Material & Generic ceiling \\
\hline \multirow[t]{2}{*}{ Floor } & Reflectance & $20 \%$ \\
\hline & Material & Generic floor \\
\hline \multicolumn{3}{|l|}{ Window parameters } \\
\hline Width (m) & & 3.66 \\
\hline Sill (m) & & 0.65 \\
\hline Lintel (m) & & 2.85 \\
\hline Glazing and transmittance & & Double clear glass $(\mathrm{VT}=80 \%)$ \\
\hline WWR & & $65 \%$ \\
\hline
\end{tabular}




\begin{tabular}{|ll}
\hline Double Skin Façade parameters & \\
\hline Façade Geometry & Multi-story DSF \\
\hline Cavity Depth & $1 \mathrm{~m}$ \\
\hline DSF glazing Material & Single clear glass $(\mathrm{VT}=88 \%)$ \\
\hline Shading system parameters & \\
\hline Shading system type & Louvers (thickness $=0.03 \mathrm{~m})$ \\
\hline Tilt angle & Horizontal Flat $\left(0^{\circ}\right)$ \\
\hline Material/ Reflectance & Sheet metal $(50 \%)$ \\
\hline
\end{tabular}

\subsection{Simulation Parameters}

The patient room was modeled using Rhinoceros modeling software. Diva for-Rhino (V. 4.0.2.1), a plug-in for Rhinoceros software, was used to interface Radiance and Daysim for annual simulation and illuminance computation (Reinhart \& Wienold, 2011). The IWEC weather file of Cairo was used to conduct annual daylighting simulations. The study took place from 8:00 AM till 6:00 PM, for seven days/week. The daylighting performance simulation work plane was set to be on the patient bed level. Two hundred seventy-four (274) analysis nodes were created on a $\left(0.9 \mathrm{~m}\right.$ height) and $\left(0.3^{*} 0.3 \mathrm{~m}\right)$ grid. These included 24 points located on the bed surface. Finally, the simulation results were collected in Microsoft Excel and then were presented in different forms.

\subsection{Daylighting Metrics and Evaluation Criteria}

Two metrics were used to assess the daylighting adequacy and visual comfort in patient rooms (IESNA, 2012). Spatial Daylight Autonomy (sDA 300/50\%) is the metric used to indicate daylight sufficiency as it describes the percentage of space floor area which received at least 300 lux for at least $50 \%$ of the annual occupied hours. Also, the Annual Sunlight Exposure (ASE 1000/250hr ) metric gives an understanding of the visual comfort by describing how much space receives an excessive amount of direct sunlight that can cause glare issues. ASE measures the percentage of floor area that receives at least 1000 lux for at least 250 occupied hours per year (IESNA, 2012). These metrics are both locationbased, which uses the actual weather data files to account for the dynamics of climatic variation in a specific location to analyze the daylight performance over the entire year (IESNA, 2012). Table (3) shows the Radiance parameters used in the simulations.

Two acceptance criteria were used for selecting the cases that achieved adequate daylighting performance. These were as follows:

\section{Criterion (1): Room Area Requirement}

Based on the LEED v.4 for healthcare facilities requirements, this criterion requires that the sDA percentage should meet a minimum requirement of $75 \%$ of the whole room area, under the condition that the percentage of the Annual Sunlight Exposure (ASE) should not exceed 10\% (USGBC, 2014). 


\section{Criterion (2): Bed Area Requirement}

As mentioned in similar papers, another criterion was taken under consideration that the sDA percentage should achieve $100 \%$ of the bed surface area (Wagdy, et al., 2017; Sherif, et al., 2016). This criterion was explicitly devised to reflect the strict needs of patient care in hospital patient rooms to aid in the healing process.

Table (2): Dimensions and parameters of the Modeled DSFs designs

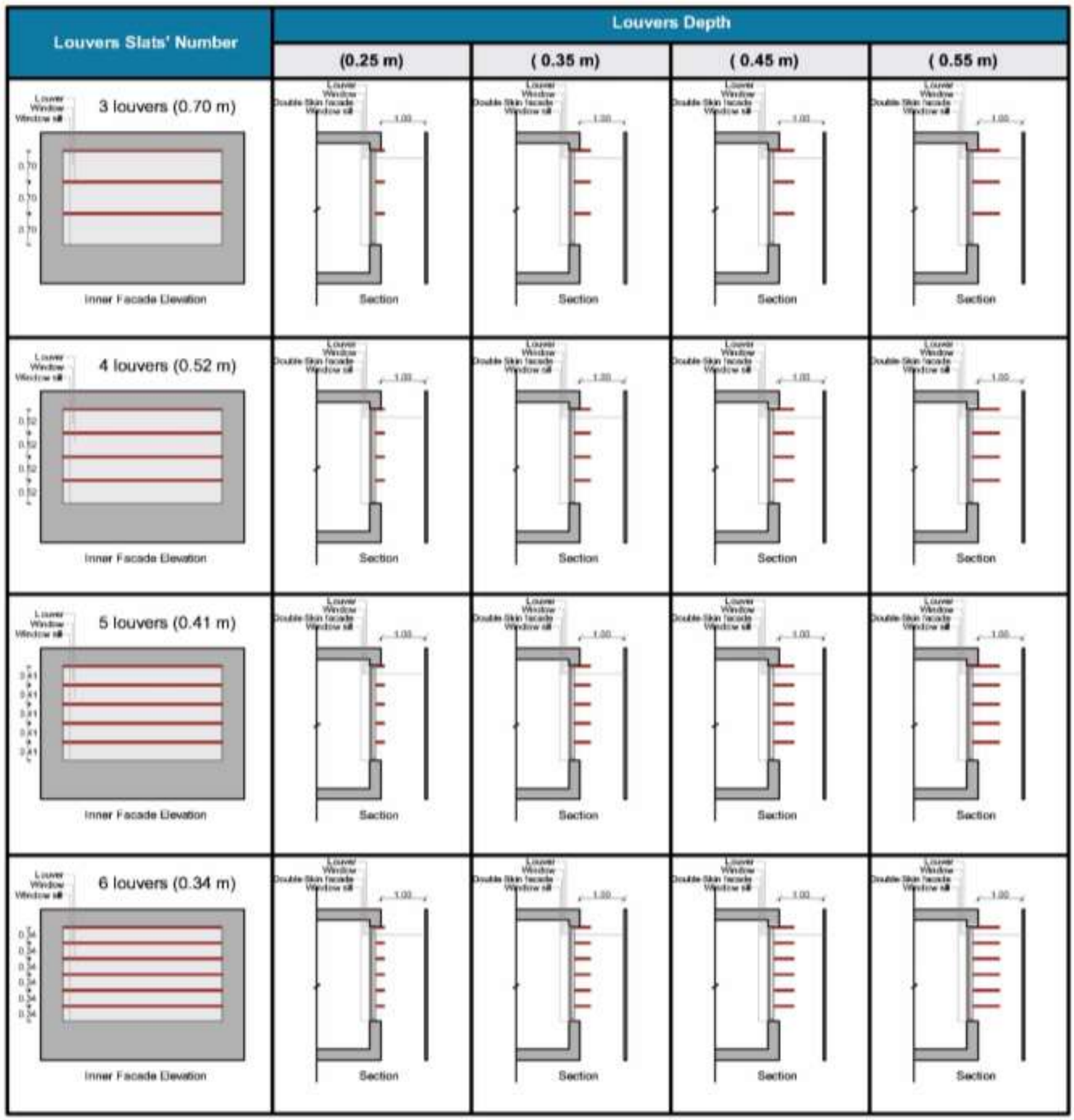


Table (3): Radiance parameters used in the simulations

\begin{tabular}{ccccccc}
$\begin{array}{c}\text { Radiance } \\
\text { parameters }\end{array}$ & $\begin{array}{c}\text { Ambient } \\
\text { bounces } \\
(\text { ab) }\end{array}$ & $\begin{array}{c}\text { Ambient } \\
\text { divisions } \\
(\mathbf{a d})\end{array}$ & $\begin{array}{c}\text { Ambient } \\
\text { sampling } \\
(\text { as })\end{array}$ & $\begin{array}{c}\text { Ambient } \\
\text { accuracy } \\
(\text { aa) }\end{array}$ & $\begin{array}{c}\text { Ambient } \\
\text { resolution }\end{array}$ & $\begin{array}{c}\text { Direct } \\
\text { threshold }\end{array}$ \\
\hline SDA & $\mathbf{6}$ & $\mathbf{1 0 0 0}$ & $\mathbf{2 0}$ & $\mathbf{0 . 1}$ & $\mathbf{3 0 0}$ & $\mathbf{0}$ \\
\hline ASE & $\mathbf{0}$ & $\mathbf{1 0 0 0}$ & $\mathbf{2 0}$ & $\mathbf{0 . 1}$ & $\mathbf{3 0 0}$ & $\mathbf{0}$ \\
\hline
\end{tabular}

\section{Simulation Results}

The base case which had no louvers achieved 100\% sDA value on the bed area, which is acceptable for the second criteria. However, it failed to achieve the first acceptance criteria as it reached SDA value of $55 \%$ and ASE value of $38 \%$ of the patient room floor area which is considered unsuccessful performance. Four louver depths were investigated $(0.25$, $0.35,0.45,0.55 \mathrm{~m})$ combined with four louvers' slats number $(3,4,5,6$ louvers $)$. The combination of changing louver's depths and number of slats resulted in 16 double-skin configurations. Results showed that all cases were successful in meeting the second criteria achieving $100 \%$ sDA value on the bed plane area. However, the louvered double-skin façade designs resulted in different SDA and ASE values at the room floor area, as illustrated in Table (4).

Despite that eight designs exceeded the sDA value requirement threshold for the room area, only three of them have succeeded in meeting ASE values less than $10 \%$ of the room area as shown in Figures (4) and (5). The other five designs resulted in ASE values that exceeded the $10 \%$ acceptance criteria. The most successful performance was achieved by (six louvers with $0.55 \mathrm{~m}$ depth) design as it reached $93 \%$ sDA and $0 \%$ ASE on the room area. The (six louvers with $0.45 \mathrm{~m}$ depth) design achieved the second-best performance with $82 \% \mathrm{sDA}$ and $5 \% \mathrm{ASE}$ on the room area. The third accepted performance was met by the (five louvers with $0.45 \mathrm{~m}$ depth) design with $77 \%$ sDA and $5 \%$ ASE on the room area.

All patient rooms integrated with louvered double-skin façades achieved better performance than the base case (with no louvers). Results also showed that the sDA and ASE are both considered the limiting factors for determining the accepted louvered doubleskin façade design. When considering constant louver's depth while changing the number of slats, the sDA results of the room area was increasing by the increasing of the slat's number. On the contrary, the ASE values of room area were decreased by increasing the louver's slats number. Also, when taking a closer look at the results, it can be found that the louver's depth has a directly proportional relationship with the sDA values of the room area, unlike the ASE value which decreases by the increasing of louvers' depth. 
Table (4): Modeled cases and base case simulation results.

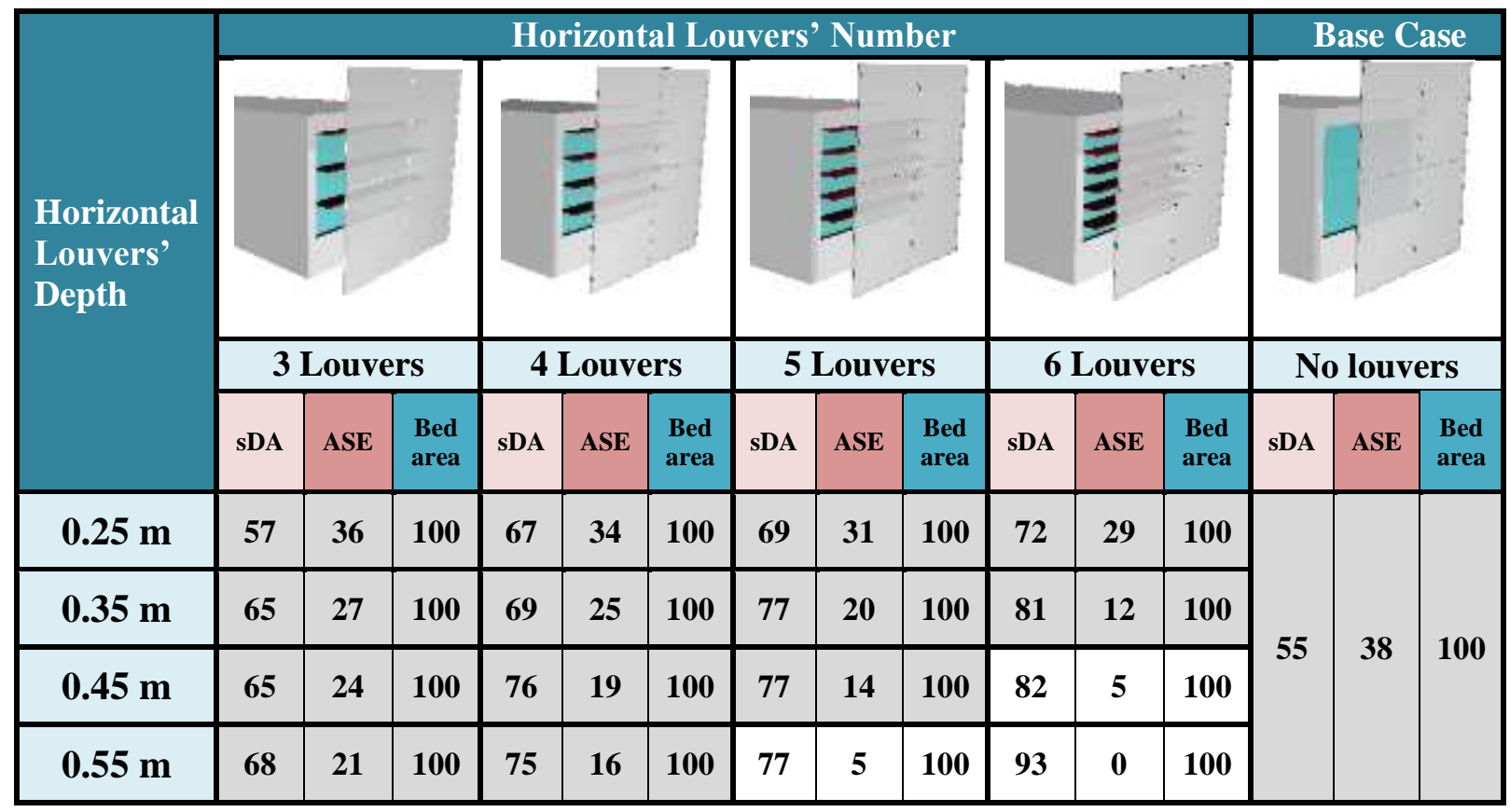

\section{sDA values chart}

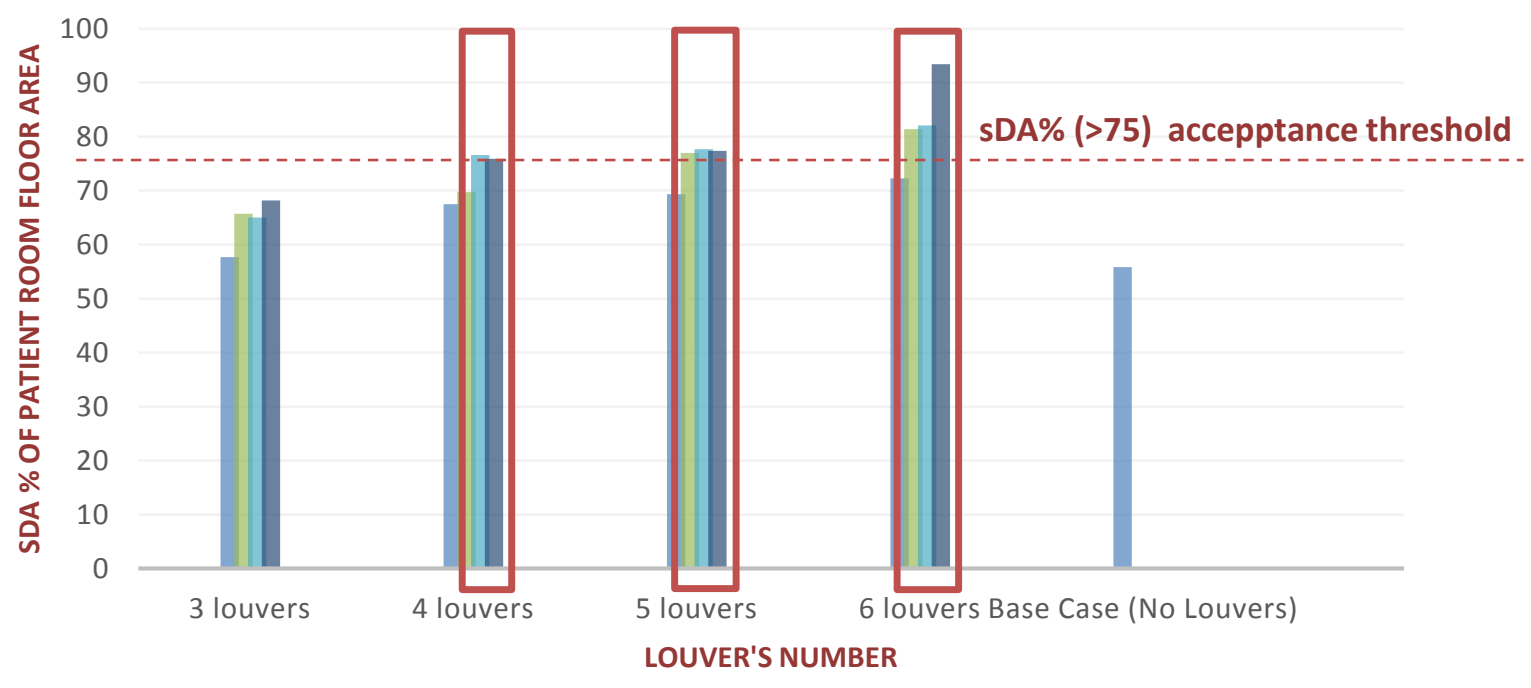

$\square(0.25 \mathrm{~m})$ louvers depth $\square(0.35 \mathrm{~m})$ louvers depth $\square(0.45 \mathrm{~m})$ louvers depth $\square(0.55 \mathrm{~m})$ louvers depth

Fig. (4): Comparison of sDA results of modeled cases and base case highlighting the successful cases. 


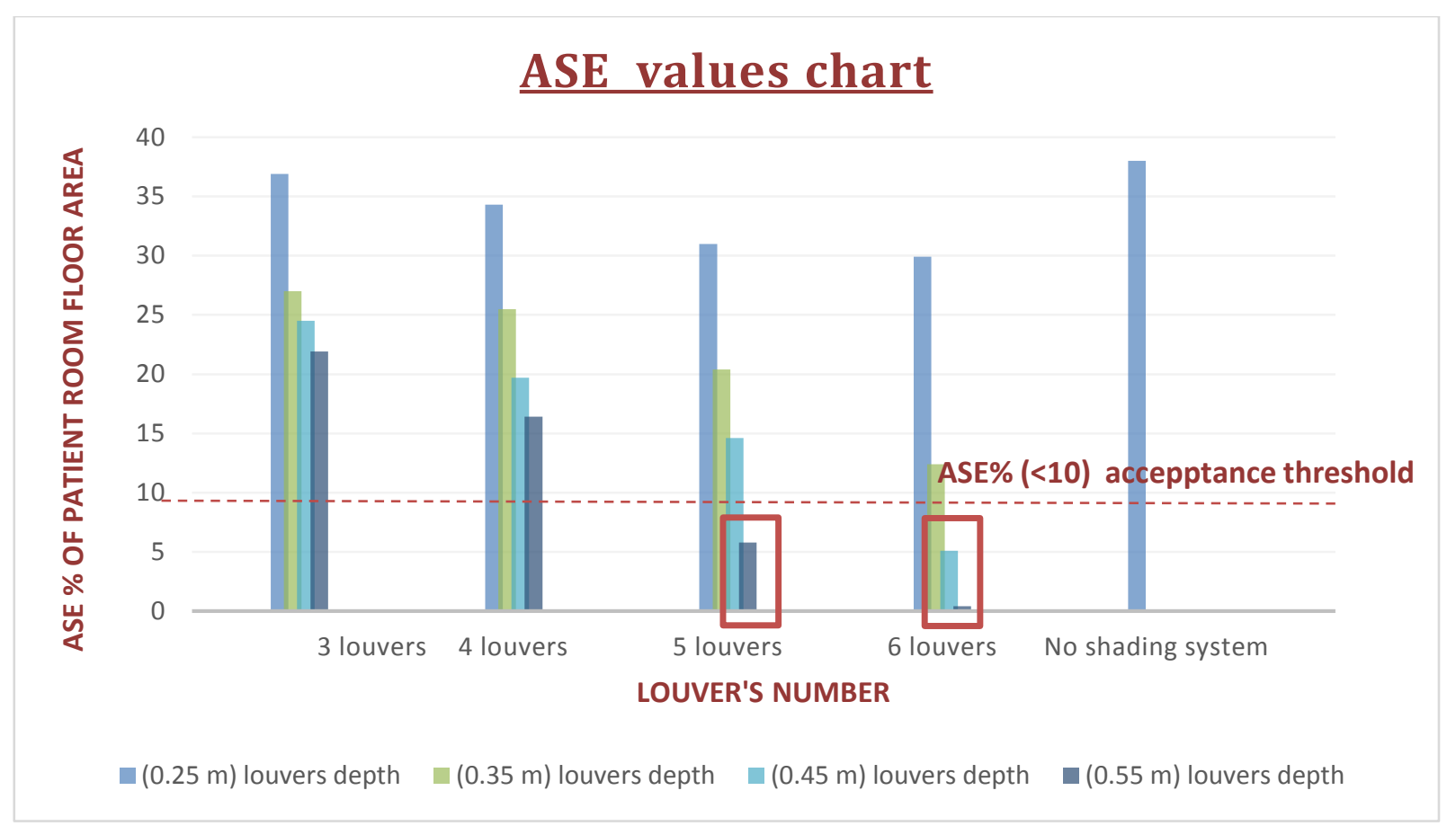

Fig. (5): Comparison of ASE results of modeled cases and base case highlighting the successful cases.

\section{Discussion and Conclusion}

This paper addressed how the integration of horizontal louvers in the cavity of a multistory double-skin façade affects daylighting performance and visual comfort of a southoriented hospital patient room. Flat horizontal louvers were used in a multi-story unobstructed double-skin façade in an inboard-bathroom patient room design oriented to the south under the clear sky conditions of Cairo, Egypt. Changing louver's depth and slats' number were investigated, which resulted in 16 shaded double-skin façade designs. Spatial Daylight Autonomy and Annual Sunlight Exposure were the two metrics used for the analysis of daylighting performance on both the patient room floor area and bed surface area. Two criteria were established to analyze daylighting performance outcomes. Based on daylight requirements of LEEDv4 for healthcare, the first criterion was $75 \%$ sDA in the room floor area while achieving less than 10\% ASE of the room area. Especially set for a patient-care needs, the second criterion focused on the bed surface area requiring a $100 \%$ sDA on the bed area.

Results showed that all the proposed double-skin façade designs with cavity integrated horizontal louvers outperformed the daylighting performance of the base case with no shading. Changing the depth and slats' number of horizontal louvers had a substantial effect on daylighting performance. Three shaded double-skin façade designs have passed the two criteria thresholds which are; the six louvers with $0.55 \mathrm{~m}$ depth DSF, the six louvers with $0.45 \mathrm{~m}$ depth DSF and the five louvers with $0.45 \mathrm{~m}$ depth DSF designs. The most successful performance was achieved by (six louvers with $0.55 \mathrm{~m}$ depth) design as it reached $93 \%$ sDA and $0 \%$ ASE of the room area. Table (5) illustrates the sDA and ASE results for successful cases. 
More focused analysis targeted the daylighting performance of 24 analysis points located on the bed surface area where important healthcare tasks take place in order to promote a healing environment. Twenty-four analysis points located on the bed surface area were studied. Results revealed that all the proposed designs were able to achieve the bed plane criteria. However, the SDA and ASE of room floor area criteria were the limiting factors.

Under the conditions of this study, using multi-story double-skin façade with no shading system is not efficient in achieving adequate daylighting performance without causing visual discomfort in patient rooms. The weak performance of the double-skin façade with no louvers showed the need for shading system integration. It can be concluded that cavity integrated horizontal shading louvers can enhance the daylighting performance of multistory unobstructed double-skin façade in south-oriented inboard-bathroom hospital patient room with $65 \%$ WWR located.

The investigation of this study was done by computer simulations conducted using the climatic data of the hot-arid climate of Cairo, Egypt (30_60N, 31_240E, alt.75 m) with clear sky conditions. Future research could target different orientations, city locations, and window to wall ratios that could result in different outcomes. Also, different patient room designs, and different types of double-skin façade can achieve different results. Further research for glare analysis should be done, since the ASE metric may not be considered as a good representation for Glare occurrence (Sherif, et al., 2016).

Table (5): sDA and ASE simulation results for successful cases.

\begin{tabular}{|l|l|l|l|}
\hline $\begin{array}{c}\text { Horizontal louvers DSF } \\
\text { configuration }\end{array}$ & sDA performance & & ASE performance \\
\hline & & & \\
\hline
\end{tabular}




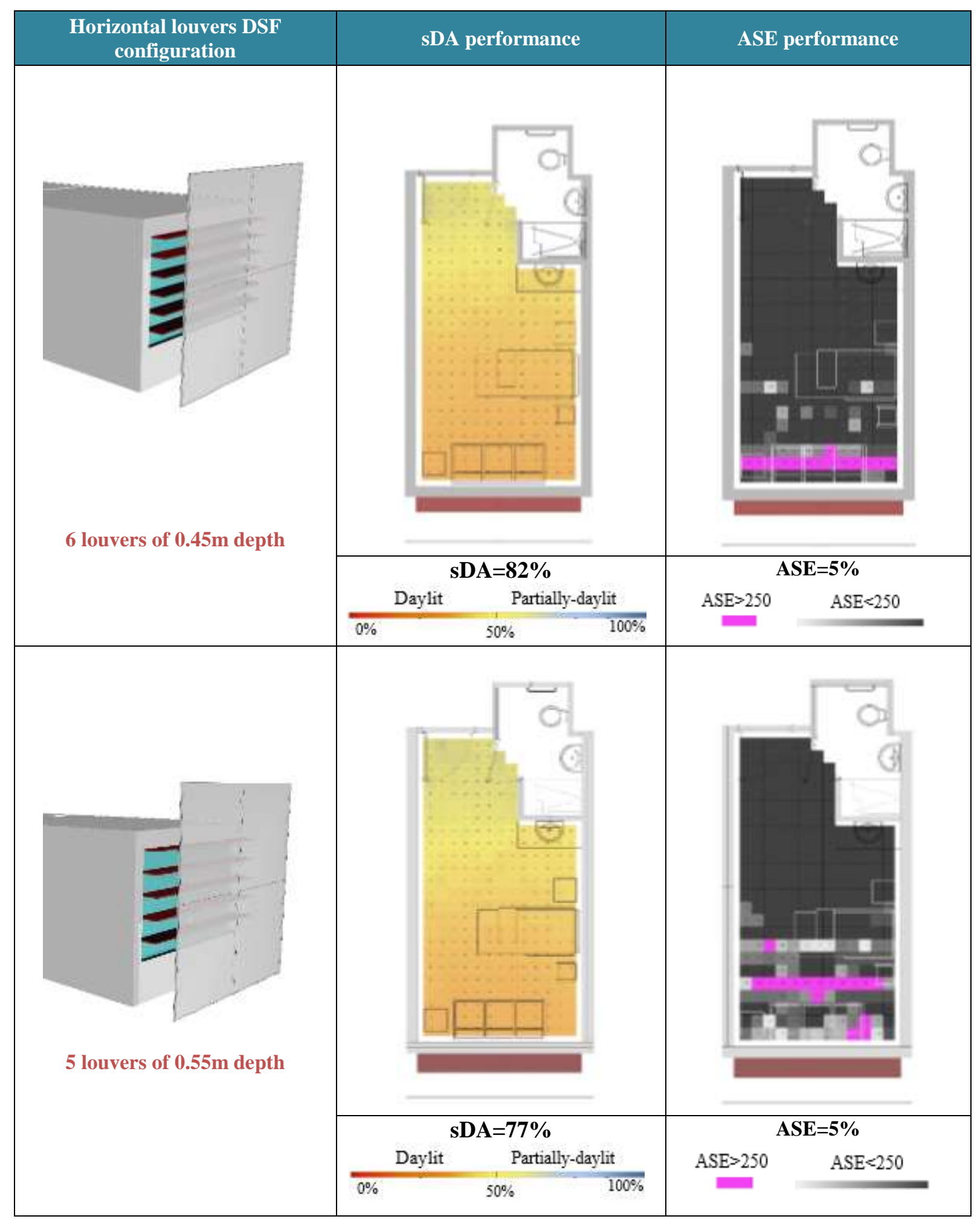




\section{References}

Aksamija, A. (2009). Context Based Design of Double Skin Facades. Perkins+ Will Research Journal, 1(1), 54-69.

Aksamija, A. (2017). Thermal, energy and daylight analysis of different types of double skin façades in various climates. Journal of Facade Design and Engineering, 6(1), 1-39.

Alzubaidi, S., Roaf, S., Banfill, P. F., Talib, R. A., \& Al-Ansari, A. (2013). Survey of hospitals lighting: Daylight and staff preferences. International Journal of Energy Engineering,, 3(6), 287-293.

Barbosa, S., \& Ip, K. (2014). Perspectives of double skin façades for naturally ventilated buildings: A review. Renewable and Sustainable Energy Reviews, 40, 1019-1029.

Choi, J. H., Beltran, L. O., \& Kim, H. S. (2012). Impacts of indoor daylight environments on patient average length of stay (ALOS) in a healthcare facility. Building and Environment, 50, 65-75.

El Ahmar, S., \& Fioravanti, A. (2015). Simulating the thermal and daylight performances of a folded porous double façade for an office building in Cairo. In Proceedings of the 49th International Conference of the Architectural Science Association (ASA).

Ghaffarianhoseini, A., Ghaffarianhoseini, A., Berardi, U., Tookey, J., Li, D. H., \& Kariminia, S. (2016). Exploring the advantages and challenges of double-skin façades (DSFs). Renewable and Sustainable Energy Reviews, 60, 1052-1065.

Ghasemi, N., \& Ghasemi, F. (2017). Double-skin Façade Technology and its Aspects in Field of Aesthetics, Environment and Energy Consumption Optimization. 293.

Ghazali, R., \& Abbas, M. Y. (2012). Assessment of healing environment in pediatric wards. Procidia-Social and Behavioural Sciences, 38, pp. 149-159.

Hamza, N., Gomaa, A., \& Underwood, C. (2007). Daylighting and thermal analysis of an obstructed double skin façade in hot arid areas. In Proceedings of Clima.

Harris, P. B., McBride, G., Ross, C., \& Curtis, L. (2002). A Place to Heal: Environmental Sources of Satisfaction Among Hospital Patients. Journal of Applied Social Psychology, 32(6), 1276-1299.

IESNA, I. (2012). LM-83-12. IES Spatial Daylight Autonomy (sDA) and Annual Sunlight Exposure (ASE). New York, NY, USA.: IESNA Lighting Measurement.

Joseph, A. (2006). The impact of light on outcomes in healthcare settings. Center for Health Design(2), 125-130.

Köppen-Geiger. (2006). World Map of Köppen-Geiger Climate Classification. Retrieved from Köppen-Geiger: http://koeppen-geiger.vu-wien.ac.at/

Mahdavinejad, M., \& Mohammadi, S. (2016). Parametric optimization of daylight and thermal performance through louvers in hot and dry climate of Tehran. Journal of Fundamental and Applied Sciences, 8(3), 1221-1236.

Mahdavinejad, M., \& Mohammadi, S. (2016). Synthesis And Optimization Of LouverDriving Mechanism For Innovative Daylighting System In Deepplan Building. The Turkish Online Journal of Design Art and Communication (TOJDAC), 6(2). Retrieved July 24, 2019, from http://acikerisim.iku.edu.tr/handle/11413/1506

Oesterle, E. (2001). Double skin facades: integrated planning; building physics, construction, aerophysics, air-conditioning, economic viability. Prestel.

Parra, J., Guardo, A., Egusquiza, E., \& Alavedra, P. (2015). Thermal performance of ventilated double skin façades with venetian blinds. Energies, 8(6), 4882-4898. 
Radhi, H., Sharples, S., \& Fikiry, F. (2013). Will multi-facade systems reduce cooling energy in fully glazed buildings? A scoping study of UAE buildings. Energy and Buildings, 56, 179-188.

Rahmani, B., Kandar, M. Z., \& Rahmani, P. (2012). How double skin façade's air-gap sizes effect on lowering solar heat gain in tropical climate. World Applied Sciences Journal, 18(6), 774-778.

Reinhart, C. F., \& Wienold, J. (2011). The daylighting dashboard e A simulation-based design analysis for daylit spaces. Building and Environment, 46, 386-396.

Sherif, A., Sabry, H., \& Gadelhak, M. (2013). Daylighting simulation as means for configuring hospital intensive care unit windows under the desert clear skies. In: Proc. of the Building Simulation Conf. (BS 2013). Chambéry, France.

Sherif, A., Sabry, H., \& Wagdy, A. (2014a). Hospital patient room design for desert climates: effect of room shape on window design for daylighting. In: Proceedings of Second Saudi Forum for Planning and Design of Hospitals. Riyadh, Saudi Arabia.

Sherif, A., Sabry, H., Arafa, R., \& Wagdy, A. (2014b). Enhancement of daylighting and external view as means for achieving a salutogenic hospital. World Health Design, Architecture, Culture, Technology, Design and Health. International Academy for Design and Health.

Sherif, A., Sabry, H., Elzafarany, A., Gadelhak, M., Arafa, R., \& Aly, M. (2015). The impact of hospital intensive care unit window design on daylighting and energy performance in desert climate. In: Proceedings of the XII International Conference on Energy,Environmental and Sustainable Development, ICEESD 2015. Paris,France.

Sherif, A., Sabry, H., Wagdy, A., \& Arafa, R. (2015b). Daylighting in hospital patient rooms: parametric workflow and genetic algorithms for an optimum façade design. In BS2015: 14th Conference of International Building Performance Simulation Association (IBPSA).

Sherif, A., Sabry, H., Wagdy, A., Mashaly, I., \& Arafa, R. (2016). Shaping the slats of hospital patient room window blinds for daylighting and external view under desert clear skies. Solar Energy, 133, 1-13.

Shikder, S., Mourshed, M., \& Price, A. (2010). Optimization of a daylight-window: hospital patient room as a test case. In: Proceedings of the International Conference on Computing in Civil and Building Engineering.

Ulrich, R. S. (1991). Effects of interior design on wellness: Theory and recent scientific research. Journal of health care interior design, 3(1), 97-109.

USGBC. (2014). LEED v4 Daylight . Retrieved July 25, 2019, from http://www.usgbc.org/credits/healthcare/v4-draft/eqc-0

Wagdy, A., Sherif, A., Sabry, H., Arafa, R., \& Mashaly, I. (2017). Daylighting simulation for the configuration of external sun-breakers on south oriented windows of hospital patient rooms under a clear desert sky. Solar Energy, 149, 164-175.

Walch, J. M., Rabin, B. S., Day, R., Williams, J. N., Choi, K., \& Kang, J. D. (2005). The effect of sunlight on postoperative analgesic medication use: a prospective study of patients undergoing spinal surgery. Psychosomatic medicine, 67(1), 156-163. 


\section{الواجهات المزدوجة في البيئات العلاجية : مدخل لتحسين أداء الإضاءة الطبيعية في غرف المرضي

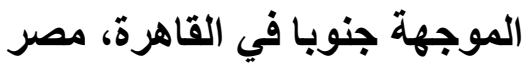

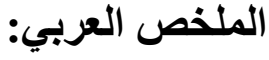

توفير الإضاءة الطبيعية يمكن أن يكون فعالا في تحقيق بيئة علاجية والتوصل إلى نتائج أفضل للرعاية

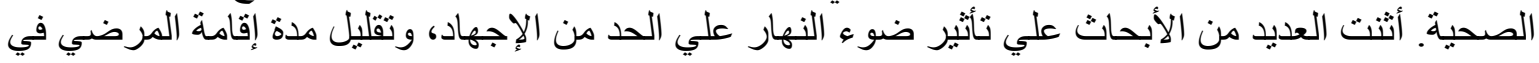

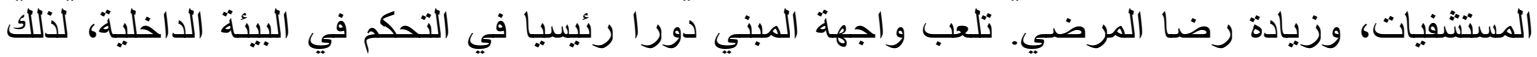

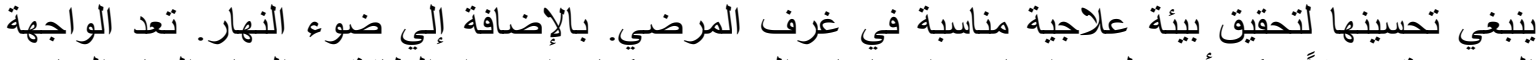
المزدوجة مدخلاً يمكن أن يخلق توازنا بين احتياجّات المرضي وكِفاءة استخدام الطاقة في المناخ الحار الجاف.

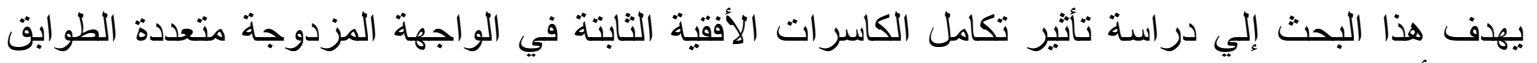

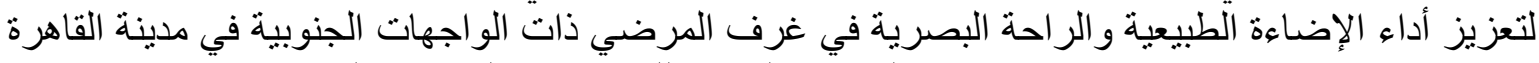

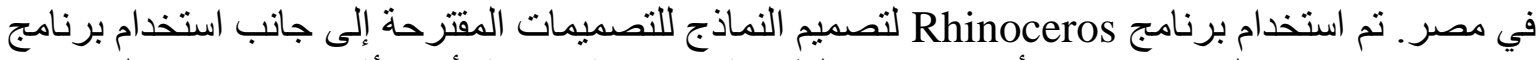

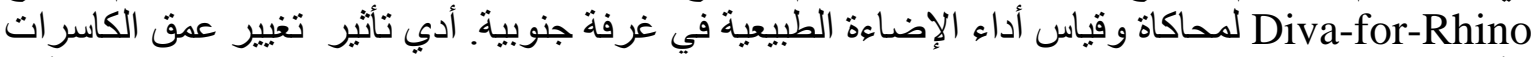

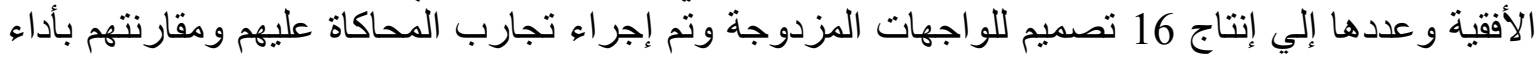
الو اجهة المزدوجة غير المظللة.

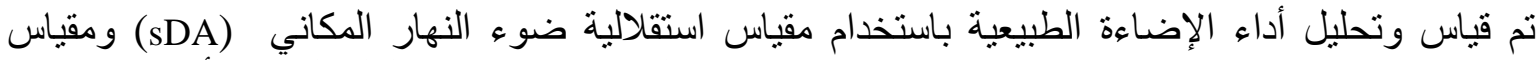

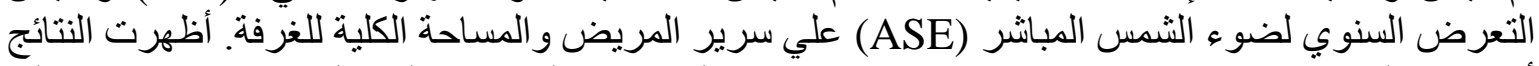

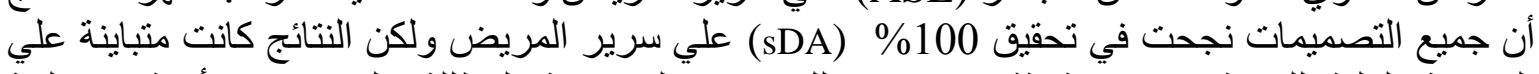

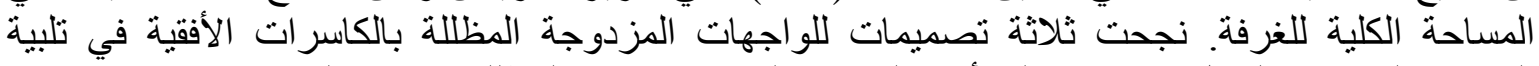
المعايير الخاصة بالقبول وتفوقت علي أداء الواجهة المزدوجة غير المظللة، وتمت التوصية باستخدامها في في غرف المرضي.

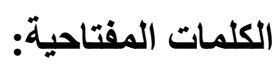
البيئة العلاجية، الوفية، الواجهات المزدوجة، غرف المرضي، أداء الإضاءة الطبيعية، استقلالية ضوء النهار المكاني، التعرض السنوي لضوء الضواء الثمس المباشر. 